\title{
Improving Accessibility: Developing Learner Agency
}

\section{Ryota Moriya \\ Otaru University of Commerce}

\section{Andrew Reimann}

Aoyama Gakuin University

\section{Shoko Moriya}

University of Tokyo

\section{Ryoko Sato \\ Reitaku University}

\section{Reference Data:}

Moriya, R., Reimann, A., Moriya, S., \& Sato, R. (2020). Improving accessibility: Developing learner agency. In P. Clements, A. Krause, \& R. Gentry (Eds.), Teacher efficacy, learner agency. Tokyo: JALT. https://doi.org/10.37546/JALTPCP2019-11

As classrooms become more diverse, the understanding of learner needs has evolved to include both visible and invisible needs. Traditionally, reasonable accommodation has been limited to supporting students with physical or cognitive requirements. This has evolved to include support for social, psychological, emotional, and even economic difficulties. Resources and institutional support remain underfunded and underdeveloped; it is therefore paramount that teachers are able to diagnose, communicate, and empathize with students who are displaying a wider range of learning needs and difficulties than ever before. Through such teacher awareness raising, we can provide scaffolding for our students and empower them to be successful. The field reports, analysis, and examples described in this study demonstrate how diverse learner needs can be better accommodated by helping learners choose or develop better learning environments for themselves. The objectives of this study were to raise awareness of diverse learner needs and share potential coping strategies.

教室における多様化が進むにつれ、学習者の二ーズも、可視化された違いだけでなく不可視化された違いも含み、その対 象を拡大してきた。合理的配慮も、社会的、精神的、そして経済的な学習困難を対象とする考え方に転換しつつある。一方で、 学習資源と教育機関の支援は未だ発展途上にある。したがって、教師が様々な困難を抱える学習者の二ーズを把握し、支援を することがこれまで以上に求められている。このような認識の転換により、教育者は多様な学習者に学びの場を提供し、学習 者の学習意欲を䁔成することができる。本稿は、様々な事例の分析を通して、学習者自身が学習環境の向上に取り組むことを 支援することが どの上うに学習者の多様なーーズの充足に結び付くのかについて明らかにする。本稿が、学習者二ーズの認 識を拡大し、教育的戦略の一つのモデルを提示し、言語教育に示唆を与えるものとなることを願う。

A s classrooms become more diverse, learners' needs change. These learners' A needs include linguistic, socioeconomic, sociocultural, and diverse learning needs. Learners with disabilities are one example. According to the Japan Student Services Organization (JASSO, 2019b), the percentage of students with disabilities in postsecondary education in Japan exceeded $1.05 \%$ in 2018 . This was a significant increase from 2014, when the percentage of students with disabilities was only $0.44 \%$. The distribution of students with different impairments in postsecondary education is $33 \%$ with weak constitution, $25.9 \%$ with mental impairment, $17.9 \%$ with developmental disability, $7.3 \%$ with physical impairment, $5.8 \%$ with hearing and speech impairment, $2.6 \%$ with visual impairment, $1.4 \%$ with multiple impairments, and $6 \%$ with other kinds of impairment (JASSO, 2019b; see Figure 1). The percentage of students with developmental disability has also shown a significant increase since 2016 (JASSO, 2019b). In 2019 , more than $1 \%$ of university students in Japan have a disability that impacts learning. In language classes, the difference between special needs and linguistic needs is often blurred or indistinguishable as these tend to be invisible differences that are not directly apparent to the teacher and can therefore also be overlooked by institutions. Therefore, special needs are not often recognized in language classes, making support or accommodation challenging. This issue has become even more serious today as 
the number of students who need Japanese language support has also been growing, exceeding 50,000 in 2019 (MEXT, 2019). These numbers show that teachers are facing a growing population of learners with diverse learning needs.

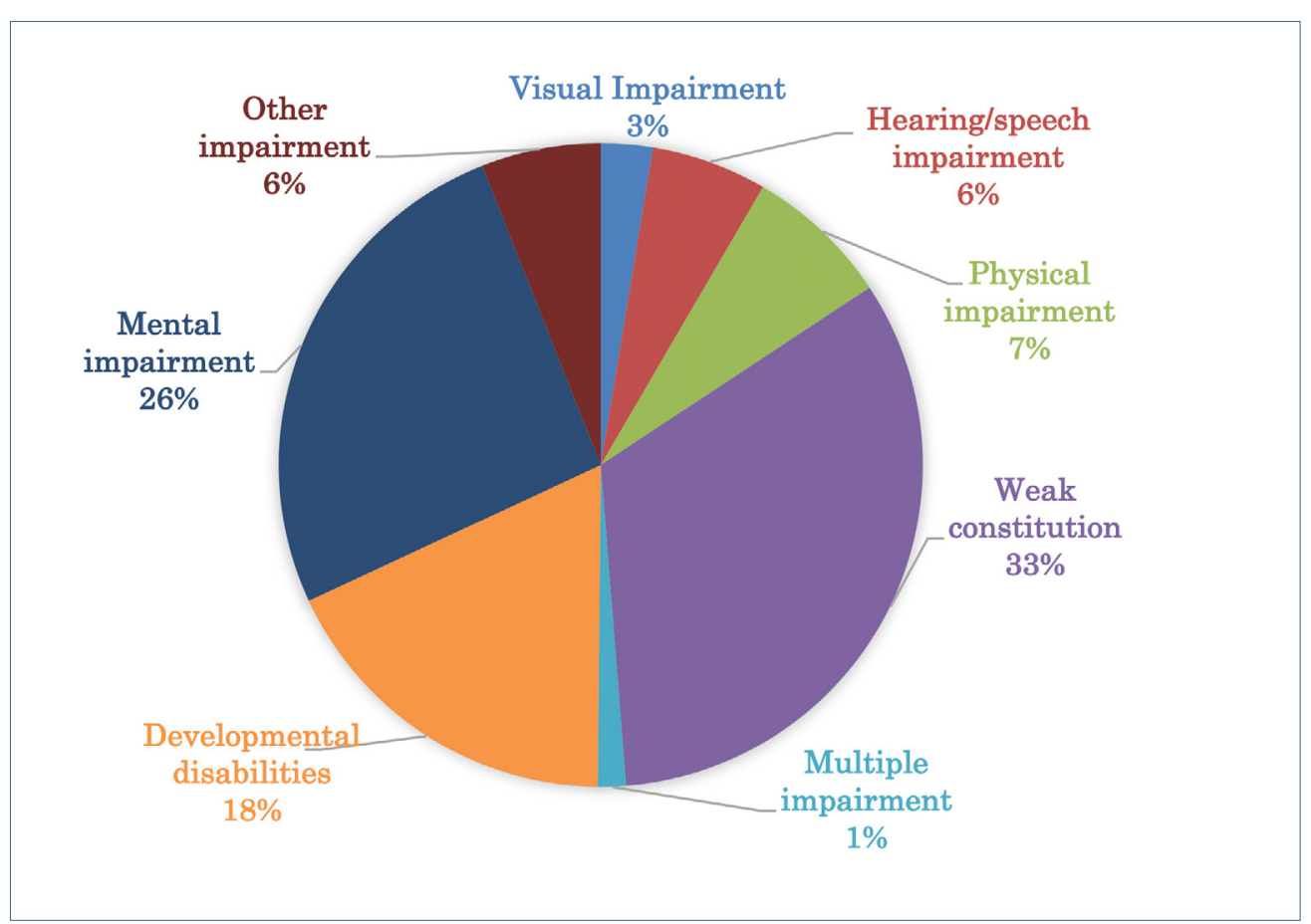

Figure 1. Percentage of different disabilities in postsecondary education (adapted from JASSO, 2019b).

According to Tonooka (2015), only $28 \%$ of university language classes in Japan offer some support for students with disabilities. In addition, only $22 \%$ of universities have full-time disability resource staff (JASSO, 2019a). This means that there are limited resources and that more pressure is placed on teachers to provide individual support for their students. In 2016, the Act for Eliminating Discrimination against Persons with Disabilities was put into effect. Although the laws only affect those in need of special needs support, realistically it is often difficult to draw a line between which difficulty requires special needs support or language support and which doesn't. Learner needs are diverse and complex. Therefore, language teachers are increasingly encouraged to be ready to make their lessons accessible for learners with diverse needs. Amendments to existing laws redefined disability as the inability to access learning resources and emphasized recognizing the learning capacity for those with special needs. In this sense, any learners with inaccessibility to learning resources, including both linguistic and other needs, are theoretically considered as learners who are disabled in language classes. In both cases these learners require not only language support but an increasingly more specialized, diverse, and not easily defined special needs support.

This particular definition of disability reflects a social model of disability in disability studies, which theoretically define disability as a social construct rather than as an impairment or disease. According to Oliver, Sapey, and Thomas (2012),

Disability is the disadvantage or restriction of activity caused by the political, economic and cultural norms of a society which takes little or no account of people who have impairments and thus excludes them from mainstream activity. Impairment is a characteristic of the mind, body or senses within an individual which is long term and may, or may not, be the result of disease, genetics or injury. (p. 16)

In the classroom, disability is caused by external factors such as inaccessible buildings and pedagogies that do not accommodate learners with diverse learning needs including those who need both special needs support and language support. The Disability Resource Centre at the University of Cambridge (2014) identified "welldesigned buildings, assistive technology, alternative formats, sign language interpreters, and inclusive workplaces with respect to independent living, inclusive methods of assessment, positive and non-discriminatory attitudes, accessible environments" (p. 1) as typical examples of accessible learning environments at their university campus. The social model of disability suggests that teachers are responsible for eliminating, or at least alleviating, inaccessibility in their classes. Under the Act for Eliminating Discrimination against Persons with Disabilities, teachers are redefined as part of the construction of disability in classrooms. Consequently, this change in legality raises the question: How can learner needs be better accommodated to improve accessibility to language learning?

This collection of case studies considers issues concerning learner needs, diversity, and accessibility in language classes in Japan. The objective of this study is to raise awareness of learners' needs by sharing coping strategies in order to help teachers as well as create a support network. Areas of focus include covert special needs observed in context, which range in nature from linguistic, cognitive, social and psychological to cultural. Several field studies and examples of social psychological needs, specific learning needs, and 
Japanese language support needs are described and discussed by the three authors, who examine context, issues, and coping strategies that apply to classroom-based experiences. In all cases, informed consent was obtained to use the data reported here, as was institutional clearance (where applicable).

In the first field study, the author explores three examples of disabilities and inaccessibility that were observed in class, with the aim of providing an alternative perspective to learners' needs assessment in language teaching. In the second field study, the author examines the learning needs of a student with Specific Learning Differences (SpLDs) in class, implying that teacher's awareness of diverse learner needs and an accessible support system are the key for the student in question to effectively learn languages in class. In the third field study, the author investigated Japanese monolingual environments at a part-time night high school (often called yakan teijisei koukou in Japanese). Based on the findings, the author suggests that language teachers may be able to empower students with diverse needs by creating opportunities to reflect upon their own identities and goals in class. By thoroughly exploring the three field studies that focus on different learner needs, the overall goal of this study is to better understand diverse and complex learner needs in language teaching in context.

\section{Social Psychological Needs}

Considering that learning disabilities are, in essence, an inaccessibility to social resources that consequently limits participation, opportunities for learning, and general productivity or engagement, it is important that teachers are able to recognize and accommodate such differences and facilitate the active and equal participation of all learners. Students differ in many ways and have a variety of challenges when participating in any given lesson or activity. These may not be readily apparent or may manifest themselves in behaviors that at first glance seem to be the result of poor attitudes, such as disruptive, rude, or antisocial actions. When students display such behavior, it is common for teachers to resort to discipline rather than empathy. It is important for teachers to have an open mind when evaluating such students and to consider the range of variables that could cause any given behavior. The following is a report on examples when invisible differences (that were social and psychological in nature) were very difficult to diagnose or determine as they were only observable in behavior problems that would typically be resolved through discipline. The purpose of this analysis is to provide a critical incident for raising awareness on alternative means of special needs assessment for helping a diverse range of students have equal access to resources and achieve the highest levels of productivity possible.

\section{Context}

The following behavioral patterns were observed in communication seminar classes ranging in size from 20 to 25. Students were majoring in International Studies at a national university and had a high-intermediate level of English. Classes met once per week for 90 minutes and the teacher knew almost half of the students from a previous class. Students' needs and preferences were therefore familiar and some level of rapport had already been established.

\section{Issues}

In the course of the seminar, three examples of students with special needs became apparent. The first student (Student A) displayed poor attitude, low motivation, and antisocial behavior, was constantly making excuses, and was distracted and confrontational. The second student (Student B) often slept in class, was frequently late or absent, and was unable to complete most assignments. The third student (Student C) acted aloof and entitled, would prioritize socializing and chatting, was obsessed with their phone, and was very sensitive and defensive about any comment or slight criticism. At first analysis these issues appeared as behavior problems signifying a bad attitude, laziness, or rude behavior. In such cases, discipline, reprimand, warning, or a discussion on manners should have helped to prevent the negative behaviors from recurring. However, the students did not respond positively to any form of verbal comment on their behavior. After careful evaluation, an alternative and more productive diagnosis was possible.

\section{Coping Strategies}

All three students had difficulty accessing resources and participating actively and productively. Each case benefitted from the teacher having an open mind towards traditional behaviors and typical needs, flexibility towards communication and deadlines, an overall empathy, and increased awareness of trying to understand each student's perspective.

Student A was experiencing economic hardship: She was highly motivated but could not access resources because of not being able to purchase technology for research and productivity (a personal computer) or a device for communication, socialization, and interaction (a smartphone). This caused a feeling of shame and a subsequent bad attitude. Only through one-on-one meetings and informal discussions was it possible for the teacher to learn about, understand, and make accommodations for an otherwise 
invisible socioeconomic difference. Student B suffered from narcolepsy. This was initially misdiagnosed, and the student himself thought he was just lazy, selfish, and stupid. After getting a second doctor's opinion and an official diagnosis and note, both the student and the institution were able to make some minor changes and accommodations that allowed the student to participate to his fullest potential. This completely changed the student's attitude, self-esteem, and motivation. Student $C$ was diagnosed with narcissistic personality disorder. Similarly, after this issue was properly understood, accommodation could be made. This student was particularly happy to be a leader and take initiative, provided they could get credit and praise for their extra efforts. In all cases, communication, flexibility, and understanding were all that was needed to transform disruptive students into productive students.

If teachers believe that everyone deserves a fair chance and that we should strive to provide the best learning opportunity for each student, then we must also try our best to accommodate diverse learning needs and difficulties. All students are essentially good students; no one wants to fail or is intentionally bad, rude, or disruptive. With this in mind, we all have the power to empower.

\section{Specific Learning Needs}

According to JASSO (2019a), 6,047 students in higher education in Japan have developmental disabilities, that is about $0.02 \%$ of the entire population of Japanese higher education institutions. Aproximately, $3.5 \%$ of them have a Specific Learning Disability (SLD). Although the number is lower than that of other developmental disability types, three out of every 100 students would show a symptom or symptoms of SLD three out of 100 students with developmental disabilities would show a symptom or symptoms of SLD. Although the letter $D$ in SLD usually stands for disabilities in most contexts in Japan, it stands for differences in most educational scenes in the United States, where the term specific learning differences (SpLDs) is more frequently used as a general umbrella term (Takeda, 2019). In the following case study, SpLDs may be a more suitable term, because the learner showed multiple symptoms that seemed to be a combination of disabilities and difficulties in learning.

\section{Context}

This student studies at a university in Chiba Prefecture. When she enrolled at the university, she asked for the researcher's support. She eventually volunteered to be a participant in this study. The researcher interviewed the student at her office at the beginning and the end of the semester. The interviews were conducted when the student faced difficulties in learning in foreign language classes. To identify the concrete problems in the courses, the researcher sometimes directly asked the teachers about how the student was doing in their classroom as necessary.

\section{Issues}

The student was diagnosed with dyslexia and dysgraphia, reading and writing disabilities. According to her descriptions, it is hard for her to read letters on white paper, particularly katakana and the Roman alphabet. Although she can recognize each letter, she has difficulty decoding at the same pace as others and reads significantly more slowly, she develops fatigue after reading for a while and often skips a line when reading a passage. It is harder for her to read English texts than Japanese texts, but it is unknown what factors prevent her from fluent reading in English. She also displays some symptoms of writing difficulties, which come from a developmental coordination disorder (a motor-skills disorder), affecting her eyes, ears, and hands. She mentions she often loses the sense of her hand while writing, preventing her from writing along ruled lines or into columns. She has also been given a diagnosis of ADHD, which frequently overlaps with dyslexia (International Dyslexia Association, 2020). Moreover, she is very sensitive to everyday sounds such as the noise of an air conditioner, the sound of turning over a piece of paper, or other environmental sounds such as coughing and chatting.

\section{Coping Strategies}

This student took a lot of action to build herself a better learning environment. At university entrance examinations, she asked the universities to extend the time, took the tests in a separate room, and used noise-canceling headphones to cut off noise. After she had enrolled at the university, she submitted an official request for reasonable accommodations and distributed a description of her SpLDs to each teacher at the beginning of each semester in order to allow her to access the contents of the courses and learning resources. This document included a detailed description of her SpLDs, cognitive characteristics, ICT skills, and learning styles, which seemed to be helpful for teachers. Staff members of the Support Room for Students with Disabilities supported her negotiations with the teachers. Because she took some foreign language courses that were taught by non-Japanese teachers who did not understand Japanese well, she had to translate the document into English or explain it in English. It was challenging for her due to the level of her English proficiency. She asked a teacher for help with the English translations and was able to convey her requests accurately in English. After submitting an application for 
reasonable accommodations, she was allowed to use a laptop to read textbooks, receive most handouts as PDF files so she could use a screen reader, and use noise-cancelling headphones to enable her to access the written information at a similar pace as classmates in most classes. Sometimes she used a reading tracker when she needed to read printed materials. The teachers came to understand her condition and individual needs.

This student was quite hard working and tried to find better ways to learn by consulting with university counselors and staff of the Support Room for Students with Disabilities. This student showed us that learners need an active agency. However, she still struggles with learning in required English courses. All teachers try to support her, but it might be impossible to teach her entirely effectively. One of the reasons is that most teachers lack a basic knowledge of SpLDs and have limited experience in teaching students with SpLDs such as dyslexia and dysgraphia. It is difficult for university teachers to adjust their classes to accommodate the student's SpLDs. Because she understands this, the student submits updated documents and official request forms for reasonable accommodations at the beginning of every semester, so both the student and her teachers can look for solutions.

It is essential for teachers to teach students explicitly and empower them to ask for help if necessary in order to make a more comfortable learning environment for themselves. For example, teachers can introduce relevant vocabulary and phrases such as "I get a headache from the sound. Can I go to the restroom and drink some water?" It can be challenging for students to admit their weaknesses, so this is effective, especially in foreign language classes taught in the target language. Students would likely hesitate to ask for help without this vocabulary and confidence in using the language. Also, teachers can demonstrate how to ask for help, such as to borrow a pen during class, by modeling useful phrases such as "I forgot a pen. May I borrow yours?"

It is also essential to raise teachers' awareness of SpLDs. They need not only basic knowledge but also a deeper understanding of students' negative learning experiences. Without this awareness, it is difficult for teachers to notice students' various difficulties. In the worst case, students struggling with learning are just ignored or misunderstood. Teachers should understand that many students have had painful experiences and perhaps have lost confidence in learning. Teachers need concrete, explicit instructions at each step of learning in order to become more active and supportive. Accessible or flexible resources or materials would particularly be useful for teachers. Everybody is different; everybody has various learning strategies. Teachers need to know about SpLDs and the way that symptoms can vary in each individual student so that they can find various ways of supporting students to accommodate their strengths and weaknesses.
Obviously, teachers cannot do everything, and institutions need to take the initiative and coordinate efforts to provide systematic educational support. If the institution created a database of coping strategies used by teachers with students, this would provide a reference and practical professional support that teachers would be able to apply immediately. The database should also include coping strategies used by students, because college students are becoming independent, preparing to enter the workforce. They need to develop agency, autonomy, confidence, and the ability to ask for help. In addition, sharing experiences is necessary to develop an effective educational support system.

\section{Japanese Language Support Needs}

Context

Being non-Japanese is not usually considered to be a disability. However, students who need Japanese language support have been traditionally treated as students with special needs in the Japanese education system. Therefore, viewing the need for Japanese language support as a socially disabled condition can help us develop a more accessible learning environment for linguistically and socioculturally diverse students. The following case study took place at a part-time night high school, a type of school where classes are held in the late afternoon and evening. It is part of the Japanese national education system established after the second world war. Students in part-time night high school have traditionally been diverse in several ways including age, socioeconomic status, and academic achievement. Many part-time night high school students have experienced so-called futoukou (absenteeism in school) in elementary school or junior high school. These students have been typically labeled as students with psychological and learning problems. In addition, these schools tend to have a high ratio of students from multilingual backgrounds (children of foreign parents working in Japan, children of parents in an international marriage, and so forth). Therefore, although the majority of students are Japanese monolingual, the number of multilingual students has been increasing in part-time night high schools (Sakuma, 2015). Some students are highly competent in Japanese; however, there is also an increasing number of students whose Japanese ability is extremely limited. In spite of this linguistic diversity, part-time night high schools are generally monolingual Japanese environments, which creates unique challenges for students with limited Japanese language knowledge.

During the fieldwork study at a part-time night high school in the Kanto area between 2015 and 2017, several classes were studied in order to understand sociocultural differences. English classes were observed, and students and teachers were interviewed 
regarding their images of, ideas about, and attitudes towards English and other languages. According to one teacher at the school, almost $40 \%$ of the students either had originally come from foreign countries or had parents from foreign countries. Some of these only had very limited Japanese knowledge and therefore understanding Japanese instruction was a challenge.

\section{Issues}

The students with limited Japanese knowledge all had very diverse issues. The focus of this case study is one male student from the Philippines. He worked at construction sites and in a factory during the day before coming to the school. Although he spoke Tagalog, the Philippine national language, it was not his first language. His Japanese was very basic; it was hard for him to follow Japanese instructions in classes. He participated in Japanese language classes designed for non-Japanese-speaking students only in the 1st and 2nd years. After he became a 3rd-year student, he was not offered supplementary Japanese classes, although his Japanese was insufficient to understand class content.

This student's English proficiency was also an issue. English class was probably the easiest class for him because the content was very basic. He seemed to have learned English at school in the Philippines, but, his lack of English vocabulary and grammatical knowledge created difficulties in communicating in the class. He usually did not participate in class, instead looking at his smartphone or listening to music through earphones. The dilemma here is that he was able to obtain credit for the English classes, which are essential requirements for his high school diploma, but he was not given enough chances to develop his English (and other academic) skills, which would be important after graduation. The case of this Filipino student shows issues related to both Japanese and English learning by non-Japanese-speaking students. The curriculum at the part-time night high school, which included a diversity of students that was increasing, was basically designed for the monolingual majority: Japanese-speaking students whose English knowledge is limited.

As Jim Cummins (2001) proposed, multilingual knowledge, which people from different cultural backgrounds possess, should be regarded as an important asset for the countries in which they live. However, the very strong monolingual ideology and identity in Japan seem to hinder the creation of spaces where such multilingual and multicultura knowledge can be shared, developed, or applied. How can teachers make classes beneficial for those who do not fit this mood or reach students like the Filipino student?

\section{Coping Strategies}

First, how can teachers raise awareness of the importance of students' multilingual competence to transform a monolingual perspective into a multilingual perspective? Their multilingual knowledge could be used to create a place where such students might be regarded as social assets and consequently feel increased motivation, self-esteem, and self-efficacy. In addition, teachers need tools for assessment of multilingual students' competencies not only in Japanese but also in other languages, especially their first languages, to which far less attention has been paid in schools in Japan. Although there have been several attempts to develop standardized assessment forms for students' Japanese language abilities and to expand the use of these (see Ishii, 2017), it seems to be extremely rare for teachers to have access to systems to assess multilingual students' linguistic competences other than Japanese and English. Indeed, with such first language assessment systems, teachers would be able to understand the needs of multilingual students, even without having multilingual knowledge themselves. Knowledge about students' multilingual competences would enable teachers to create more accessible environments for students in need of Japanese language support.

Lastly, it is of great importance for teachers to consider students' sociocultural backgrounds. In the case of the Filipino student, his work during the daytime seemed physically demanding, it was not clear whether or when he would go back to the Philippines, and his expectation of schools may have differed from the reality. Considering these aspects of the student would have helped his teachers understand his complex situation.

\section{Conclusion}

This paper explored three different learning contexts about which various coping strategies were discussed in the hope of improving accessibility to language learning. Each context is different. However, the coping strategies discussed in these case studies reflect a social model of disability in which learner needs are a form of sociocultural inaccessibility to resources in language learning. In this sense, the paper will conclude with a discussion of the ways in which diverse learner needs can be better accommodated in the language learning process.

Various copings strategies were suggested in order to manage complex environments and individual differences and considering how teachers can accommodate learner needs in complex and diverse classrooms. In one case study, a student who was experiencing economic hardship. Although the student was motivated, she could not purchase a PC 
or a communication device. This financial difficulty prevented her from accessing any educational learning resources. It required careful evaluation by the teacher to make an alternative and more productive diagnosis; otherwise the student's financial needs could have been misread as poor attitude, low motivation, and antisocial behavior. At the institutional level, another alternative might involve providing financial support for such students because their financial difficulties may deter them from focusing on classes.

Teachers can advocate for financial support for those students who might otherwise not be qualified. A flexible and open-minded approach to coping strategies could improve accessibility to language learning for learners with diverse needs, by accommodating their individual needs to create better learning environments.

It is also important for teachers to manage or bridge differences in learning styles or environments by encouraging students with diverse learning needs to become advocates for their own needs. Many students with socioeconomic problems may not advocate for their needs because they do not feel comfortable sharing their personal issues with their teachers. Other students with multicultural and multilingual backgrounds may not have a chance to reflect on their cultural and linguistic identities in the Japanese monolingual environment at school. Teachers might facilitate discussion regarding financial issues, multicultural and multilingual identities, and individual learning goals in class, to help students develop a coping strategy. This may empower students with diverse needs to be motivated and to improve learning experiences for themselves. Consequently, the chance for better accommodation of these students in language classes may increase.

Finally, it is important to consider the relationship between learner diversity and accessibility in language teaching. Learner needs are diverse, and they become special needs or disabilities in classrooms where accessibility to learning is constricted. Such accessibility may be improved by facilitating student self-advocacy. Correspondingly, coping strategies are also diverse. A network or database of case studies, examples, and critical incidents would be useful for language teachers, so that they can apply diverse coping strategies to their classes and improve accessibility. Creating such a database may be an effective strategy to improve accessibility in language learning. It may also be effective to create groups of language teachers who share the same awareness that learners with special needs are an important part of their teaching practice. The findings of this study imply that cooperation, communication, and collaboration as well as the formation of a special interest group that focuses on accessibility in language learning may improve learning experiences of learners with diverse needs in language classes.

\section{Acknowlegment}

This research was partially supported by JSPS KAKENHI Grant Number 18J10348.

\section{Bio Data}

Ryota Moriya is currently a lecturer in the Glocal Education Division of the Center for Glocal Strategy at Otaru University of Commerce. He has a PhD in international studies. His research interests include color-blindness, disability studies, accessibility in language learning, and Foucauldian genealogical discourse analysis. <ryota.moriya@gmail.com>

Andrew Reimann is an associate professor and language program coordinator in the English Department at Aoyama Gakuin University in Tokyo. He has a PhD in applied linguistics, focusing on intercultural communication and materials design. He teaches classes on comparative culture and intercultural communication. His research interests include raising cultural awareness, communication strategies, and media literacy. Recent publications include Culture Studies Handbook, Culture in Context (Intergraphica Press, 2016) and Humor for Cross Cultural Analysis (TESOL, 2017).<anreimann@yahoo.com>

Shoko Moriya is currently a doctoral student in the Department of Language \& Information Sciences, Graduate School of Arts \& Sciences of the University of Tokyo and a research support member for Research Institute of Business Administration, Waseda University. Her research interests include language ideology and English education at part-time night high schools. <shokott@gmail.com>

Ryoko Sato is a lecturer of the Faculty of Foreign Studies, Reitaku University. She is also a doctoral student in the department of English and Cultural Studies of Tsuda University. Her research interests include language education and special needs education, especially for students with developmental disabilities. <rsato@reitaku-u.ac.jp>

\section{References}

Cummins, J. (2001). Negotiating identities: Education for empowerment in a diverse society (2nd ed.). Los Angeles: California Association for Bilingual Education.

The Disability Resource Centre at the University of Cambridge. (2014). The social model of disability. Retrieved from http://www.admin.cam.ac.uk/univ/disability/support/social.html

International Dyslexia Association. (2020). Attention-deficit/hyperactivity disorder (AD/HD) and dyslexia [Fact sheet]. Retrieved from https://app.box.com/s/3t48u8ofwc9w3ml6yu11mydtzropz9ud 
Ishii, E. (2017). 子どもの日本語教育 [Japanese language education for children]. In E. Tajiri (Ed.), 外国

人労働者受け入れ之日本語教育 [Acceptance of foreign workers and Japanese language education] (pp. 183-209). Tokyo: Hituji Shobo.

JASSO. (2019a). 平成30年度 (2018年度) 大学、短期大学及び高等専門学校における障害のある学生の修学 支援に関する実態調查結果報告書 [A report of learning support services for students with disabilities in higher education institutions (2018 fiscal year)]. Retrieved from https://www.jasso.go.jp/gakusei/ tokubetsu_shien/chosa_kenkyu/chosa/__icsFiles/afieldfile/2019/07/22/report2018_2.pdf

JASSO. (2019b). 「平成30年度 (2018年度) 大学、短期大学及び高等専門学校における障害のある学生の修学 支援に関する実態調査] 結果の概要等について [A summary of a report of learning support services for students with disabilities in higher education institutions (2018 fiscal year)]. JASSO press. Retrieved from https://www.jasso.go.jp/gakusei/tokubetsu_shien/chosa_kenkyu/chosa/__icsFiles/ afieldfile/2019/03/15/press2018.pdf

MEXT. (2019). 「日本語指導が必要な児童生徒の受入状況等に関する調查 (平成30年度)」の結果につい $\tau$ [ Findings from the survey (2018 fiscal year) regarding acceptance of and other issues related to students who need Japanese language support]. Retrieved September 30, 2019, from https://www.mext.go.jp/content/1421569_002.pdf

Oliver, M., Sapey, B., \& Thomas, P. (2012). Social work with disabled people (4th ed.). Basingstoke, Hampshire, England: Palgrave Macmillan.

Sakuma, K. (2015). 多国籍化する日本の学校:教育グローバル化の衝撃 [Multinationalizing schools in Japan: Impacts of educational globalization]. Tokyo: Keisou Shobou.

Takeda, K. (2019). LDについてーLDの定義からいかに診断/判断を行うのか [About LD - How to make a diagnosis/judgment from the definition of LD]. In S. Konuki S., M. Murayama, M., \& S. Ogasawara (Eds.). LDの“定義”を再考する [Rethink the ‘definition’ of LD] (pp. 32-40). Tokyo: Kanekoshobo.

Tonooka, T. (2015). 高等教育機関(大学)に掠ける合理的配慮·学習支援 [Reasonable accommodation/ learning support in higher education institutions (universities)]. 福祉労働 [Welfare Labor], 146, 60-66. 